\title{
PENGARUH KEPEMILIKAN MANAJERIAL, KEPEMILIKAN INSTITUSIONAL, DAN KEBIJAKAN DIVIDEN PADA PERUSAHAAN MANUFAKTUR YANG TERDAFTAR DIBURSA EFEK INDONESIA PERIODE 2014-2015
}

\author{
SILIN \\ e-mail: siliny@ymail.com \\ Nanang Purwanto \\ Rita Indah Mustikowati \\ (Program Studi Akuntansi, Fakultas Ekonomi, Universitas Kanjuruhan, Malang)
}

\begin{abstract}
ABSTRAK
Tujuan penelitian ini adalah untuk menguji dan menjelaskan pengaruh kepemilikan manajerial, kepemilikan institusional dan kebijakan dividen terhadap kualitas laba yang terdaftar di bursa efek indonesia (BEI) tahun 2014-2015. Populasi dari penelitian ini adalah perusahaan sektor perbankan yang terdaftar di Bursa Efek Indonesia. Pengambilan sampel menggunakan metode purposive judgement sampling. Dari populasi sebanyak 139 perusahaan manufaktur diperoleh 15 perusahaan manufaktur sebagai sampel dengan metode pengamatan selama 2 tahun (2014-2015). Analisis data yang digunakan dalam penelitian ini adalah uji asumsi klasik dan uji hipotesis. Metode penelitian yang digunakan dalam penelitian ini adalah metode deskriptif kuantitatif. Sedangkan metode analisis yang digunakan adalah analisis regresi linier berganda. Hasil penelitian ini menunjukan bahwa variabel kepemilikan manajerial, kepemilikan institusional dan kebijakan dividen berpengaruh signifikan terhadap kualitaslaba baik secara parsial maupun secara simultan. Variabel kebijakan dividen memiliki pengaruh paling dominan terhadap kualitas laba.
\end{abstract}

Kata kunci - kepemilikan manajerial, kepemilikan institusional, kebijakan dividen, kualitas laba

\section{ABSTRACT}

The purpose is to examine and explain the effect of managerial ownership, institutional ownership and dividend policy on the quality of earnings listed on the Indonesia Stock Exchange (IDX) in 2014-2015. The population of this study is the banking sector companies listed on the Indonesia Stock Exchange. Sampling uses a purposive judgment sampling method. From a population of 139 manufacturing companies, 15 manufacturing companies were obtained as samples with the observation method for 2 years (2014-2015). Analysis of the data used in this study is the classic assumption test and hypothesis test. The research method used in this research is quantitative descriptive method. While the analytical method used is multiple linear regression analysis. The results of this study indicate that the variables of managerial ownership, institutional ownership and dividend policy have a significant effect on the quality of profits both partially and simultaneously. Dividend policy variables have the most dominant influence on earnings quality.

Keynotes - managerial ownership, institutional ownership and dividend policy, quality of earnings 


\section{PENDAHULUAN}

Industri manufaktur indonesia menunjukkan pertumbuhan yang baik. Berdasarkan laporan statistik berjudul "Internatitonal Yearbook Of Industrial Statistic 2016", Industri manufaktur di indonesia dilaporkan telah memberikan kontribusi hampir seperempet bagian dari produk domestik brotu (PDB) nasional. Indeks manufaktur yang sebagian besar komponen pembentuknya terdiri atas indeks consumer, industri dasar, dan aneka industri, naik 9\% sejak awal tahun 2013. Terjaganya pertumbuhan sektor ini berdampak terhadap peningkatan pendapatan perusahaan yang bergerak dimanufaktur. Maka, sangat beralasan apabila investor mengapresiasi positif saham-saham manufaktur. (Setianingsih, 2016), dan juga kebanyakan investor berpandangan akan membeli sebuah perusahaan dengan pertimbangan laba perusahaan dimasa yang akan datang (future earnings) yang ada dalam laba tahun berjalan yang dilaporkan oleh perusahaan. Menurut Suwardjono (2010: 464), laba dimaknai sebagai imbalan atas upaya perusahaan menghasilkan barang dan jasa. Teori agensi menekankan pentingnya pemilik perusahaan (pemegang saham) menyerahkan pengelolaan perusahaan kepada tenaga-tenaga profesional (agen) yang lebih mengerti dalalam menjalankan bisnis sehari-hari (Adrian, 2015:76). Perbedaan dari pihak prinsipal dan agensi meyebabkan timbulnya kesenjangan informasi atara pemegang saham dan organisasi. Herawaty (2008:8), menyatakan kepemilikan saham oleh investor institusional bahwa invetor institusional merupakan pihak yang memonitoring agen dengan kepemilikanya yang besar, sehingga motivasi manajer untuk mengatur laba menajadi berkuarang. Adapun faktor-faktor yang mempengaruhi dalam pebuatan dividen menurut Sjahrial (2002:179) yaitu, posisi likuiditas perusahaan, kebutuhan dana untuk membayar hutang, rencana perluasan usaha dan pengawasan terhadap perusahaan.

Penelitian Oktaviani, Nur, dan Ratnawati (2015), Hasil dari penelitian ini menunjukkan bahwa kepemilikan manajerial, kepemilikan institusional, dewan komisaris, dewan dirieksi berpengaruh siginifikan terhadap kualitas laba. Wilsna Rupilu (2011), Hasil penelitian ini menunjukkan bahwa kepemilikan manajerial dan kepemilikan institusional dan komite audit berpengaruh secara positif terhadap kualitas laba, sedangkan dewan komisaris independen tidak berpengaruh terhadap kualitas laba. Setianingsih, Lestari (2016), Hasil penelitian ini menunjukkan bahwa kepemilikan institusional berpengaruh signifikan terhadap kualitas laba perusahaan, sedangkan kepemilikan manajerial tidak berpengaruh signifikan terhadap laba. Amanita Novi Yushita (2013), Peneliti ini menggunakan GLS sebagai teknik analisis data, hasil penelitian ini menunjukkan bahwa struktur dewan direksi, komisaris independen, berpengaruh positif dan signifikan terhadap discretionary accrual (DTAC) atau berpengaruh negarif terhadap kualitas laba. Sedangakan kepemilikan manajerial, kepemilikan institusional, komite audit, likuiditas tidak berpengaruh signifikan terhadap kulalitas laba. Berdasarkan uraian latar belakang diatas, maka penelitian tertarik untuk mengadakan penelitaian dengan judul "Pengaruh Dari Kepemilikan Manajerial, Kepemilikan Institusional, Dan Kebijakan Dividen Terhadap Kualitas Laba Pada Perusahaan Manufaktur Yang Terdaftar Di Bursa Efek Indonesia (BEI) Periode 2014-2105".

\section{TINJAUAN PUSTAKA}

\section{Teori Agensi (Agency Theory)}

MenurutJesen dan Meckling (1976) agency theory adalah sebuah kontrak antara manajer (agent) dengan pemilik (principal). Sementara itu, kepemilikana perusahaan (pemegang saham) hanya bertugas untuk mengawasi dan memonitoring jalannya perusahaan yang dikelola oleh manajemen untuk memastikan bahwa mereka bekerja hanya demi kepentingan perusahaan semata (Sutedi, 2015:77).

\section{Signalling Theory}

Signalling Theory merupakan teori yang membahas mengenai bagaimana perusahaan memberikan informasi attau sinyal baik positif maupun negatif bagi pemegang saham (Scott, 2011). Menurut Melewar (2008:100), meyatakan teori sinyal menunjukkan bahwa perusahaan akan 
memberikan sinyal melalui tindakan dan komunikasi perusahaan ini mengadopsi sinyal-sinyal ini untuk mengungkapkan atribut yang tersembunyi untuk para pemangku kepentingan.

\section{Kualitas Laba}

Kualitas laba didefiniskan sebagai korelasi antara laba perusahaan secara akuntansi dan secara ekonomis (schroeder, 2009). Laba yang kurang berkualitas bisa terjadi karena adanya pemisahanan antara kepemilikan dan pengelolaan perusahaan yang dapat meninbulkan konflik yang sebut konflik keagenan (Nadirsyah dan Fadlan, 2015). Sedangkan definisi kualitas laba merupakan informasi laporan keuangan suatu perusahan mencerminkan aktivitas usaha secara akurat, sehingga memiliki laba yang berkualitas (Subramanyam, 2012). Kualitas laba memberikan inforamsi mengenai situasi dn kondisi suatu perusahaan bahwa dampak ekonomi transaksi yang terjadi akan beragam diantara perusahaan sebagai fungsi dari karakter dasar bisnis mereka, dan secara beragam dirumuskan sebagai tingkat laba yang menunjukkan apakah dampak ekonomi pokok lebih baik dalam memperkirakan arus kas atau juga dapat diramalkan.

\section{Kepemilikan Manajerial}

Enggar dan Akhmad (2013:6) menfinisikan kepemilikan manajerial merupakan saham perusahaan yang dimiliki manajemen perusahaan. Menurut Hidayati (2015), jika suatu perusahaan memiliki kepemilikan manajerial yang tinggi, manajer jauh lebih peduli tentang kepentingan pemegang saham dan opsi saham akan menjadi insentif untuk konstribusi perusahaan. Kepemilikan manajerial dalam sebuah perusahan, akan memberikan keuntungan bagi perusahaan. Transparansi dan keterbukaan akan tercapai jika terdapat kepemilikan manajerial dalam perusahaan. Peningkatan kepemilikan saham oleh manajer, diharapkan bahwa manajer akan bertindak sesuai dengan keinginan prinsipal karena manajer akan termotivasi untuk meningkatkan kinerja. Hal ini disebabkan oleh karena adanya kontrol yang mereka miliki (Nadirsyah, 2015:4).

\section{Kepemilikan Institusional}

Menurut Anggraini 2010, kepemilikan institusional merupakan salah satu alat yang dapat digunakan untuk mengurangi agency conflict. Dengan kata lain, semakin tinggi tingkat kepemilikan institusional maka semakin kuat tingkat pengendalian yang dilakukan oleh pihak eksternal terhadap perusahan sehingga agency cost yang terjadi dalam perusahaan semakin berkurang dan nilai perusahaan juga dapat semakin meningkat. Maghfiratun (2010), investor institusional melakukan monitoring perusahaan dapat dilakukan secara terbuka melalui praktik corporate governance atau secara tertutup melalui pengumpulan informasi dan dengan membenarkan harga saham yang berdampak pada pengabilan keputusan manajer

\section{Kebijakan Dividen}

Kebijakan dividen menurut deitiana (2011:61), adalah pembagian laba perusahaan yang besarnya saham telah ditetapkan dalam Rapat Umum Pemegang Saham (RUPS) kepada para pemegang saham secara proposional sesuai dengan jumlah saham yang telah dimiliki oleh masingmasing pemegang saham tersebut. Menurut Sjahrial (2007:305), perusahaan akan tumbuh dan berkembang, kemudian pada waktunya kan memperoleh keuntungan atau laba. Laba ini terdiri dari laba yang ditahan dan laba yang dibagikan. Pada tahap selanjutnya laba yang ditahan merupakan salah satu sumber dana yang paling penting untuk pembiayaan pertumbuhan perusahaan

\section{PENELITIAN TERDAHULU}

Penelitian yang dilakukan oleh Oktaviani, Nur, dan Ratnawati (2015), Hasil dari penelitian ini menunjukkan bahwa kepemilikan manajerial, kepemilikan institusional, dewan komisaris, dewan dirieksi berpengaruh siginifikan terhadap kualitas laba. Wilsna (2011), Hasil penelitian ini menunjukkan bahwa kepemilikan manajerial dan kepemilikan institusional dan komite audit berpengaruh secara positif terhadap kualitas laba, sedangkan dewan komisaris independen tidak berpengaruh terhadap kualitas laba. Setianingsih, (2016), Hasil penelitian ini menunjukkan bahwa kepemilikan institusional berpengaruh signifikan terhadap kualitas laba perusahaan, sedangkan 
kepemilikan manajerial tidak berpengaruh signifikan terhadap laba. Yushita, Rahmawati, dan Hanung (2013), hasil penelitian ini menunjukkan bahwa struktur dewan direksi, komisaris independen, berpengaruh positif dan signifikan terhadap discretionary accrual (DTAC) atau berpengaruh negarif terhadap kualitas laba. Sedangakan kepemilikan manajerial, kepemilikan institusional, komite audit, likuiditas tidak berpengaruh signifikan terhadap kulalitas laba, Febriela Sirait, (2012), Hasil penelitian menunjukkan status pembagian dividen memiliki hubungan positif yang signifikan dengan kualitas laba. Meskipun demikian, ukuran dividen yang besar tidak terbukti mengindikasikan laba yang lebih berkualitas.

Berdasarkan landasan teori dan hasil beberapa peneliti terdahulu yang telah dipaparkan sebelumnya maka kerangka konseptual penelitian ini digambarkan sebagai berikut:

\section{Kerangka pemikiran}

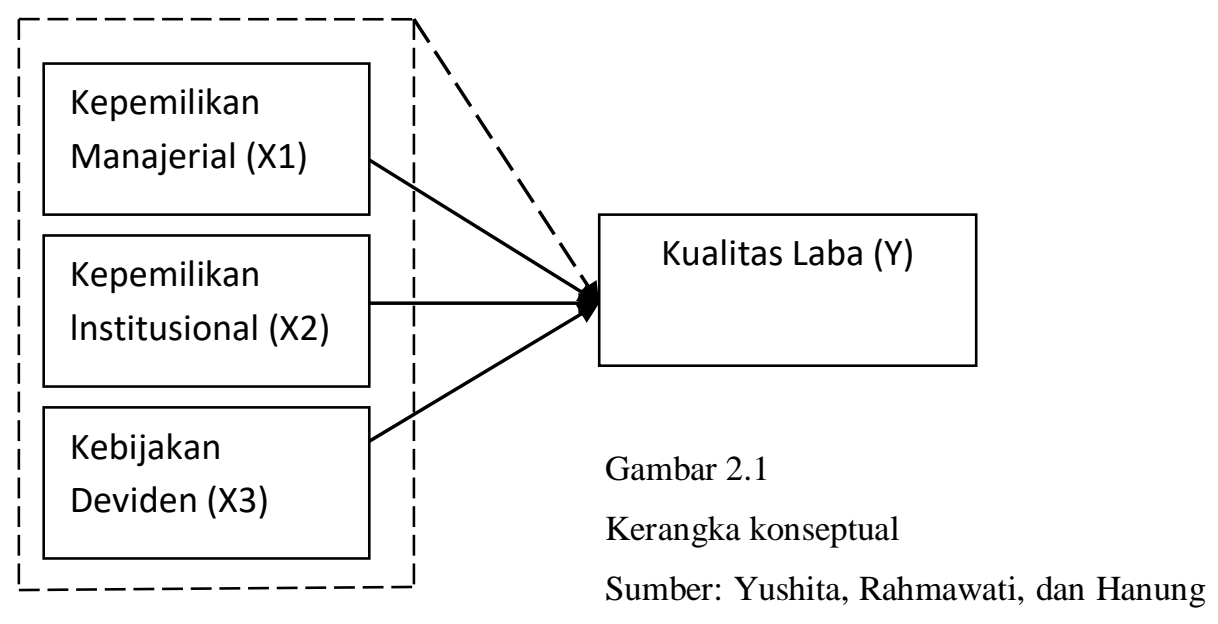

\section{Hipotesis Penelitian:}

\section{Pengaruh Kepemilikan Manajerial Terhadap Kualitas Laba}

Menurut Indrawati dan Yulianti (2010), Menyatakan kualitas laba yang dilaporkan dapat dipengaruhi oleh kepemilikan saham manajerial. Menurut Mu'id (2009), menunjukkan bahwa kepemilikan manajerial mempengaruhi kualitas laba. Hal ini berarti semakin tinggi proporsi kepemilikan manajeril maka akan semakin bagus kualitas laba yang dihasilkan, Siallagan \& Machfoedz (2006) menyatakan bahwa semakin besar kepemilikan manajerial, maka semakin rendah Discretionary Accrual. Hal ini berarti memberikan bukti bahwa kepemilikan manajerial mengurangi dorongan perilaku mementingkan kepentingan manajer secara individu

H1: Kepemilikan Manajerial Berpengaruh Terhadap Kualitas Laba

\section{Pengaruh Keputusan Pendanaan Terhadap Nilai Perusahaan}

Setianingsih, (2016) kepemilikan istitusional memiliki pengaruh signifikan terhadap kualitas laba. Menurut Indrawati dan Yulianti (2010), pandangan teori keagenan dimana terdapat pemisahaan antara pihak agen dan prinsipal yang mengakibatkan munculnya potensi konflik dapat mempengaruhi kualitas laba yang dilaporkan. Hasil penelitian ini menunjukkan bahwa kepemilikan institusional berpengaruh terhadap kualitas laba. Menurut Yushita, Rahmawati dan Hanung (2013), Hasil penelitian ini menunjukkan bawah kepemilikan institusional tidak berpengaruh terhadap kualitas laba.

H2: Kepemilikan institusional berpengaruh terhadap kualitas laba

\section{Pengaruh Kebijakan Dividen Terhadap Nilai Perusahaan}

Bird in the hand theory menyatakan bahwa dividen adalah lebih pasti daripada pendapatan modal (capital gain) dan signalling theory yang menyatakan bahwa pengumuman kenaikan dividen merupakan sinyal mengenai prospek perusahaan di masa mendatang yang baik, dan teori agengsi 
hubungan kotraktual ini dapat berjalan dengan lancar, pemilik akan menyerahkan wewenang ini kepada manajemen dengan tujuan manajemen akan mengelola perusahaan agar menghasilkan laba, dan pemilik akan mengawasi kinerja manajemen.

H3: kebijakan dividen berpengaruh terhadap nilai perusahaan.

3. Keputusan Investasi, Keputusan Pendanaan, dan Kebijakan Dividen Berpengaruh Secara Simultan dan Parsial Terhadap Nilai Perusahaan.

Hasil penelitian Setianingsih (2016),menunjukan bahwa variabel independen yang digunakan berpengaruhi secara simultan terhadap kualitas laba. Variabel independen tersebut terdiri dari kepemilikan manajerial, kepemilikan institusional dan kebijakan dividen $\mathrm{t}$

\section{METODE PENELITIAN}

\section{Rancangan Penelitian}

Model penelitian yang digunakan deskriptif kuantitatif. menyatakan pendekatan kuantitatif merupakan suatu variabel yang nilai-nilainya dinyatakan dalam bentuk numerical. Pada penelitian ini objek yang menjadi populasi adalah manufaktur yang terdaftar di Bursa Efek Indonesia (BEI) periode 2014-2015. Teknik pengambilan sampel dengan purposive judgement sampling, maka diperoleh sampel 15 perusahaan dari 139 perusahaa $n$. Adapun kriteria yang digunakan untuk memilih sampel sebagai berikut:

1. Perusahaan manufaktur yang terdaftar di Bursa Efek Indonesia (BEI) periode 2014-2015

2. Perusahaan maufaktur yang tidak memiliki kepemilikan manajerial

3. Perusahaan manufaktur yang tidak memiliki kepemilikan institusional

4. Perusahaan manufaktur yang mendapat rugi tahun berjalan dan rugi arus kas periode 20142015

5. Perusahaan manufaktur yang memiliki saham beredar periode 2014-2015

6. Perusahaan manufaktur yang memiliki EPS periode 2014-2014

\section{Ruang Lingkup Penelitian}

Peneliti memberikan batasan penelitian sehingga penelitian ini bisa fokus dan tidak melebar.

Batasan-batasan tersebut adalah sebagai berikut:

1. Perusahaan manufaktur yang terdaftar di Bursa Efek Indonesia (BEI) dan mempublikasikan laporan keuangan periode 2014-2015.

2. Perusahaan manufaktur yang melaporkan proporsi kepemilikan manajerial, kepemilikan institusional, kebijakan dividen

3. Perusahaan manufaktur yang memperoleh laba selama periode 2013-2015.

\section{Teknik Analisis Data}

\section{Analisis Regeresi Linier Berganda}

Teknik analisi. s data dalam penelitian ini dengan menggunakan analisis regresi linier berganda. menurut Sugiyono (2012), analisis regersi linier berganda digunakan untuk mengetahui pengaruh variabel independen yang jumlahnya lebih dari satu terhadap variabel dependen. Dalam penelitian ini, analisis regresi linear berganda digunakan untuk menguji hipotesis yang menyatakan bahwa kepemilikan manajerial, kepemilikan institusonal, dan kebijakan dividen secara bersamasama berpengaruh terhadap kualitas laba.

Hubungan linier ini secara sistematis digambarkan dalam rumus sebagai berikut:

$\mathrm{Y}=\alpha+\beta 1 \mathrm{X} 1+\beta 2 \mathrm{X} 2+\beta 3 \mathrm{X} 3+\mathrm{e}$

Dimana:

$\mathrm{Y}=$ Kualitas Laba

$\alpha \quad=$ Konstanta

$\beta 1-\beta 3=$ Slope atau Koefisien Regresi

$\mathrm{X} 1=$ Kepemilikan Manajerial

X2 = Kepemilikan Institusional 
Silin, Pengaruh Kepemilikan Manajerial, Kepemilikan Institusional, Dan Kebijakan Dividen Pada Perusahaan Manufaktur Yang Terdaftar Dibursa Efek Indonesia Periode 2014-2015

$$
\begin{array}{ll}
\mathrm{X} 3 & =\text { Kebijakan Dividen } \\
\mathrm{e} & =\text { error term (kesalahan pengganggu) }
\end{array}
$$

\section{Analisis Statistik Deksriptif}

Analisis statistik deskriptif bertujuan untuk memberikan gambaran atau deskripsi suatu data yang dilihat dari nilai rata-rata (mean),standar deviasi, varian, maksimum, minimum, sum, range, kurtosis, dan skewness (kemiringan distribusi) (Ghozali, 2013).

\section{Uji Asumsi Klasik}

\section{- Uji Normalitas}

Uji normalitas ini bertujuan untuk menguji apakah data berdistribusi normal atau tidak dilakukan uji statistik Kolmogorov-Smirnov Test. Residual berdistribusi normal jika memiliki nilai signifikansi $>0.05$ atau 5\% (Ghozali, 2013).

\section{- Uji Multikolinieritas}

Uji multikolinieritas bertujuan untuk menguji apakah model regresi ditemukan adanya korelasi antar variabel bebas (independen). Untuk menguji multikolinieritas adalah dengan melihat nilai VIF(Variance Inflation Factor).Jika nilaiVIF $<10$, dapat disimpulkan data bebas dari gejala multikolinieritas. Dengan kata lain model yang baik seharusnya tidak terjadi korelasi di antara variabel bebas (independen) (Ghozali, 2013).

\section{- Uji Autokorelasi}

Uji autokorelasi ini bertujuan untuk menguji apakah dalam model regresi ada korelasi antara kesalahan pengganggu pada periode $t$ dengan kesalahan pengganggu pada periode $t-1$ (sebelumnya). Jika terjadi korelasi, maka dinamakan ada problem autokorelasi (Ghozali, 2013). Salah satu cara yang dapat digunakan untuk mendeteksi ada tidaknya autokorelasi adalah uji Durbin-Wiston (DW test).

\section{- Uji Heteroskedastisitas}

Uji ini bertujuan menguji apakah dalam model regresi terjadi ketidaksamaan variance dari residual satu pengamatan kepengamatan yang lain metode Scatterplot. Jika ditemukan pola bergelombang, melebar, kemudian menyempit maka telah terjadi heteroskedastisitas. Model yang baik seharusnya tidak terjadi heteroskedastisitas tetapi homoskedastisitas (Ghozali, 2013).

\section{Uji Hipotesis Regresi Parsial (uji-t)}

Uji stastitik - $\mathrm{t}$ digunakan untuk mengetahui seberapa jauh pengaruh satu variabel independen secara dependen (Ghozali, 2013).

\section{Uji Signifikansi Simultan (Uji Stastitik F)}

Uji signifikansi simultan menunjukan pengujian pengaruh variabel independen yang dimaksudkan dalam model mempunyai pengaruh secara bersama-sama (simultan) terhadap variabel dependen (Ghozali, 2013).

\section{Uji Koefisien Determinasi $\left(R^{2}\right)$}

Nilai koefisien determinasi adalah antara nol dan satu. Semakin kecil nilai $\mathrm{R}^{2}$ maka, kemampuan variabel independen dalam menjelaskan variabel dependen dalam menjeaskan variasi variabel dependen semakin terbatas (Ghozali, 2013).

\section{PEMBAHASAN}

\section{A. PENGUJIAN ASUMSI KLASIK}

\section{Hasil Uji Normalitas}

Hasil uji asumsi klasik normalitas dilakukan uji statistik Kolmogorov-Smirnov Test. Menunjukkan bahwa nilai signifikan 0,209 yaitu >0,05. Residual berdistribusi normal jika memiliki nilai signifikansi $>0,05$ atau 5\% (Ghozali, 2013). Jadi uji tersebut menunjukkan bahwa data berdistribusi normal.

\section{Hasil Uji Multikolinieritas}


Berdasarkan hasil uji SPSS dapat dilihat bahwa variabel keputusan investasi, keputusan pendanaa, dan kebijakan dividen memiliki nilai tolerance sebesar 1.427, 1.834, dan 1.563 menunjukkan bahwa semua variabel nilai VIF lebih kecil dari 10, maka ketiga variabel tersebut dinyatakan tidak terdapat gejala multikolinieritas.

\section{Hasil Uji klasik autokorelasi}

Menggunakan pendekatan Durbin Watson. Hasilnya disajikan pada Lampiran 3. Pada lampiran tersebut menunjukkan bahwa nilai Durbin Watson 1,723 terletak diantara 1,55-2,46 (Firdaus, 2010). Hasil ini menunjukkan bahwa tidak terjadi autokorelasi.

\section{Hasil Uji Heteroskedastisitas}

Hasil uji asumsi klasik heteroskedastisitas dengan pendekatan Scatter Plot disajikan pada Lampiran 4. Dari gambar grafik Scatter Plot menunjukkan baha titik-titik menyebar secara acak serta tersebar baik diatas maupun dibawah angka 0 pada sumbu Y. Dengan demikian dapat disimpukan bahwa tidak terjadi Heteroskedastisitas pada model regresi.

\section{B. Hasil Analisis Regresi Linier Berganda}

Hasil analisis regresi linier berganda disajikan pada Lampiran 5. Dari Lampiran tersebut dapat dibuat persamaan regresi sebagai berikut:

$$
\begin{aligned}
\mathrm{Y}=\alpha+\beta 1 \mathrm{X} 1+\beta 2 \mathrm{X} 2+\beta 3 \mathrm{X} 3+\mathrm{e} \\
\mathrm{Y}=0,924+2,617 \mathrm{X} 1+2,419 \mathrm{X} 2+0,002 \mathrm{X} 3+\mathrm{e}
\end{aligned}
$$

Berdasarkan pada persamaan diatas dapat dijelaskan sebagai berikut:

1. Koefisien regresi variabel KM bertanda positif 2,617. Artinya mengindikasikan bahwa variabel TAG berhubungan positif dengan QIR. Jika variabel TAG dinaikan 1 satuan, maka nilai QIR akan naik 2,617 satuan. Asumsi variabel lainnya tdak berubah.

2. Koefisien koefisien regresi variabel KI bertanda positif 2,419 . Hal ini mengindikasikan bahwa variabel KI berhubungan positif dengan kualitas laba. Jika variabel KI dinaikan 1 satuan, maka kualitas laba akan naik 2,419 satuan. Asumsi variabel lain tidak berubah.

3. Koefisien regresi variabel EPS bertanda positif 0,002. Hal ini mengindikasikan bahwa variabel EPS berhubungan positif dengan kualitas laba. Jika EPS dinaikan 1 satuan, maka kualitas laba akan naik 0,002 satuan. Asumsi variabel lain tidak berubah.

4. Nilai R-square 0,580 persen mengindikasikan bahwa perubahan atau naik turunnya kualitas laba 58 persen dipengaruhi oleh variabel KM, variabel KI, Variabel EPS. Sedangkan 42 persen dipengaruhi oleh variabel lain yang tidak diteliti, seperti ukuran perusahaan, rasio pembayaran dividen dan komite audit

Hasil Uji Statistik Deskriptif

Hasil analisis dengan menggunakan statistik deskriptif terhadap kepemilikan manajerial (KM) menunjukkan nilai minimum sebesar 0,298 nilai maksimum 5,721 dengan rata-rata 1,20907 dan standar deviasi 1,106817. Hasil analisis dengan menggunakan statistik deskriptif terhadap kepemilikan institusional (KI) menunjukkan nilai minimum sebesar 0,0000, nilai maksimum 0,4370 dengan rata-rata sebesar 0,084867 dan standar deviasi 0,1330636. Hasil analisis dengan menggunakan statistik deskriptif terhadap kebijakan dividen (EPS) menunjukkan nilai minimum sebesar 0,058, nilai maksimum 0,881 dengan rata-rata sebesar 0,61907 dan standar deviasi 0,219872. Hasil analisis dengan menggunakan statistik deskriptif terhadap kualitas laba (QIR) menunjukkan nilai minimum sebesar 1.06 nilai maksimum 942,05 dengan rata-rata sebesar 201,05 dan standar deviasi 265,975.

\section{Uji Hipotesis}

\section{Hasil Uji Hipotesis Pertama}

Hasil uji hipotesis pertama menunjukkan bahwa nilai signifikansi uji-t variabel Kepemilikan Manajerial (KM) sebesar 0,001 lebih kecil dari 5\%. Hal ini berarti bahwa secara parsial variabel kepemilikan manajerial berpengaruh terhadap Quality Income Of Ratio (QIR). Dengan demikian, 
Silin, Pengaruh Kepemilikan Manajerial, Kepemilikan Institusional, Dan Kebijakan Dividen Pada Perusahaan Manufaktur Yang Terdaftar Dibursa Efek Indonesia Periode 2014-2015

hipotesis pertama yang menyatakan bahwa variabel Kepemilikan Manajerial (KM) secara parsial berpngaruh terhadap Quality income Of Ratio (QIR diterima.

\section{Hasil uji hipotesis kedua}

Hasil uji hipotesis kedua tampak bahwa nilai signifikansi uji-t variabel kepemilikan institusional (KI) sebesar lebih kecil 0,000 dari alpa 5\%. Hasil ini berati bahwa secara parsial variabel Kepemilikan Institusional (KI) berpengaruh terhadap Quality Income Of Ratio. Dengan demikian, hipotesis kedua yang menyatakan bahwa variabel Kepemilikan Institusional (KI) berpengaruh terhadap Quality Income Of Ratio diterima.

\section{Hasil uji hipotesis ketiga}

Hasil uji hipotesis ketiga tampak bahwa nilai signifikansi uji-t variabel Earning Per Share (EPS) sebesar lebih kecil 0,018 dari alpa 5\%. Hasil ini berati bahwa secara parsial variabel Earning Per share (EPS) berpengaruh terhadap Quality Income Of Ratio. Dengan demikian, hipotesis kedua yang menyatakan bahwa variabel Kepemilikan Institusional (KI) berpengaruh terhadap Quality Income Of Ratio diterima.

\section{Hasil uji hipotesis keempat}

Hasil uji statistik F menggunakan uji ANOVA arau $\mathrm{F}$ test, didapat nilai $\mathrm{F}$ sebesar 8,156 dengan tingkat signifikansi 0,000. Karena signifikan lebih kecil dari 0,05, sehingga dapat disimpulkan bahwa variabel kepemilikan manajerial, kepemilikan institusional, dan kebijakan dividen berpengaruh secara simultan terhadap variabel kualitas laba.

Koefisien Determinasi $\left(\mathbf{R}^{2}\right)$

Berdasarkan analisis yang diperoleh nilai adjusted $R$ Square sebesar 0,333 atau 33.3\%, artinya bahwa keragaman QIR dipengaruhi oleh variabel KM, dll sedangkan sisanya yaitu sebesar $66.7 \%$ dipengaruhi oleh variabel lain diluar variabel yang diteliti.

\section{KESIMPULAN}

Berdasarkan hasil penelitian yang telah dilakukan, dapat disimpulkan bahwa variabel kepemilikan manajerial yang diproksikan dengan jumlah saham yang dimiliki manajerial dengan jumlah lembar saham beredar secara parsial memiliki pengaruh positif signifikan terhadap kualitas laba perusahaan manufaktur. Variabel kepemilikan institusional yang diproksikan denan jumlah saham yang dimiliki institusional dengan jumlah saham beredar secara parsial memiliki pengaruh yang signifikan terhadap kualitas laba perusahaan manufaktur. Variabel kebijakan dividen diproksikan dengan earning per share berpengaruh secara parsial berpengaruh positif signifikan terhadap kualitas laba perusahaan manufaktur. Uji F menunjukkan bahwa variabel kepemilikan manajerial, kepemilikan isntitusional, dan kebijakan dividen secara simultan berpengaruh signifikan terhadap nilai perusahaan dan kebijakan dividen merupakan variabel yang paling dominan dari kepemilikan manajerial dan kepemilikan institusional dalam mempengaruhi kualitas laba

\section{Daftar Pustaka}

Ghozali, Imam (2013). Aplikasi Analisis Multivariate dengan Program SPSS. Cetakan ke V. Semarang : Badan Penerbit UNDIP.

Herawaty, Vinola. 2008. Peran Praktek Coporate Governance Sebagai Moderating Variabel Dari Pengaruh Earning Management Terhadap Nilai Perusahaan. Jurnal Akuntansi dan Keuangan.

Indrawati dan Yulianti. 2010. Mekanisme Corporate Governance dan Kualitas Laba. Jurnal. Vol.2, No.2, Juli 2010. Online 31 Oktober 2016 4:22 
Silin, Pengaruh Kepemilikan Manajerial, Kepemilikan Institusional, Dan Kebijakan Dividen Pada Perusahaan Manufaktur Yang Terdaftar Dibursa Efek Indonesia Periode 2014-2015

Nadhirsyah dan Fadlan. 2015. Struktur Modal, Good Corporate Governance dan Kualitas Laba. Jurnal. Vol.2 (2), pp.184-198. Diakses 2 Novemeber 2016 00:57

Setianingsih, Lestari. 2016. Pengaruh Investment Opportunity Set, Likuiditas, dan Good Corporate Governance terhadap Kualitas Laba Pada Perusahaan.jurnal. Fakultas Ekonomi Akuntansi Universitas Pandanaran Semarang.

Siallagan, dan Mas'ud. 2006. Mekanisme Coporate Governance, Kualitas Laba dan Nilai Perusahaan. Jurnal. Diakses 9 November 2016. 22:23

Sirait, Febriela. 2012. Hubungan pembagian Dividen Dengan Kualitas Laba. Skripsi. Fakultas Ekonomi Universitas Indonesia.

Sjahrial, Dermawan,2007. “Manajemen Keuangan". Edisi 4. Jakarta : Mitra Wacana Media.

Subramanyam, KR, dan Wild, John J. (2010). Analisi Laporan Keuangan. Edisi Bahasa Indonesia. Terjemahan Oleh Dwi Yanti. Jakarta : Salemba Empat.

Sugiyono. 2012. Memahami Penelitian Kualitatif. Bandung. ALFABETA.

T. C Melewar (2010). Teori akuntansi. http://ioaddakhil.blogspot.co.id/2014/02/pengertian-teorisinyal.html. Diakses 26 november 2016

Sutedi, Adrian. Buku Pintar Perseroan Terbatas. (2015). Penerbit Raih Asa Sukses : Jakarta.

Yushita, Rahmawati dan Hanung (2013). Pengaruh Mekanisme Corporate Governance, Kualitas Auditor Eksternal, dan Likuiditas Terhadap Kualitas Laba. Jurnal, Universitas Negeri Yogyakarta, indonesia. Diakses 28 Oktober 2016. 22:34 